Grand Valley State University

ScholarWorks@GVSU

Summer 7-2000

\title{
Nestling Tree Swallow (Tachycineta bicolor) Diets in an Upland Old Field in Western Michigan
}

Matthew E. Johnson

Grand Valley State University

Michael P. Lombardo

Grand Valley State University, lombardm@gvsu.edu

Follow this and additional works at: https://scholarworks.gvsu.edu/biopeerpubs

Part of the Poultry or Avian Science Commons, and the Zoology Commons

\section{ScholarWorks Citation}

Johnson, Matthew E. and Lombardo, Michael P., "Nestling Tree Swallow (Tachycineta bicolor) Diets in an Upland Old Field in Western Michigan" (2000). Peer Reviewed Publications. 4.

https://scholarworks.gvsu.edu/biopeerpubs/4

This Article is brought to you for free and open access by the Biology Department at ScholarWorks@GVSU. It has been accepted for inclusion in Peer Reviewed Publications by an authorized administrator of ScholarWorks@GVSU.

For more information, please contact scholarworks@gvsu.edu. 
Nestling Tree Swallow (Tachycineta Bicolor) Diets in an Upland Old Field in Western Michigan



\author{
Matthew E. Johnson; Michael P. Lombardo
}

American Midland Naturalist, Vol. 144, No. 1. (Jul., 2000), pp. 216-219.

Stable URL:

http://links.jstor.org/sici?sici=0003-0031\%28200007\%29144\%3A1\%3C216\%3ANTS\%28BD\%3E2.0.CO\%3B2-H

American Midland Naturalist is currently published by The University of Notre Dame.

Your use of the JSTOR archive indicates your acceptance of JSTOR's Terms and Conditions of Use, available at http://www.jstor.org/about/terms.html. JSTOR's Terms and Conditions of Use provides, in part, that unless you have obtained prior permission, you may not download an entire issue of a journal or multiple copies of articles, and you may use content in the JSTOR archive only for your personal, non-commercial use.

Please contact the publisher regarding any further use of this work. Publisher contact information may be obtained at http://www.jstor.org/journals/notredame.html.

Each copy of any part of a JSTOR transmission must contain the same copyright notice that appears on the screen or printed page of such transmission.

JSTOR is an independent not-for-profit organization dedicated to creating and preserving a digital archive of scholarly journals. For more information regarding JSTOR, please contact support@ jstor.org. 


\title{
Notes and Discussion
}

\section{Nestling Tree Swallow (Tachycineta bicolor) Diets in an Upland Old Field in Western Michigan}

\begin{abstract}
We collected and identified 1852 prey items from 89 boluses delivered to 62 nestling tree swallows (Tachycineta bicolor) at 14 nests in an upland old field in western Michigan. We found that $90.8 \%$ of nestling diets was insects from the Orders Diptera, Homoptera, Hymenoptera and Coleoptera. We also found clam and snail shells in boluses. Over the most common brood sizes of 4-6 nestlings, brood size was inversely proportional to the number of items per bolus delivered to nestlings although mean dry and mean crganic weight of boluses did not differ. Bolus composition was not influenced by weather conditions. Nestling diets at our study site were similar in the proportions of many prey items, such as Diptera and Homoptera, to tree swallow nestling diets in other habitats but contained fewer aquatic forms such as Odonata and Ephemeroptera.
\end{abstract}

\section{INTRODUCTION}

The type and quality of nestling diets can provide insight into the life histories of birds. A nestling's diet affects its rate of development (Lack, 1968), nutrition (Street and McDonald, 1977) and size at fledging, which ultimately affects its probability of survival (Perrins, 1980; Smith, 1988) and adult size (Boag, 1987). Adults diversify food items fed to young to fulfill the nutritional needs of nestlings (Krebs and Avery, 1984; O’Connor, 1984).

Tree swallows feed primarily on aerial insects, but exhibit regional differences in the proportions and quantities of prey items in diets (Beal, 1918; Quinney and Ankney, 1985; Blancher et al., 1987; Blancher and McNicol, 1991). Diets of nestling tree swallows have been examined in many habitats, including wetlands (Blancher et al., 1987; Blancher and McNicol, 1991), open fields and sewage lagoons (Quinney and Ankney, 1985) and around artificial ponds (McCarty and Winkler, 1999). Variations in nestling growth have been explained by differences in local food abundance (Quinney et al., 1986).

We studied diets of nestling tree swallows in an upland old field in western Michigan to: (1) determine the types and proportions of prey items fed to nestlings by adults, (2) investigate the relationship between the number of prey items per bolus and bolus weight and brood size and (3) investigate the relationship between bolus composition and weather.

\section{METHODS}

In 1997 we assessed the diets of nestling tree swallows reared in wooden nest boxes mounted on metal poles erected in a grid in an upland old field on the campus of Grand Valley State University, Ottawa County, Michigan $\left(42^{\circ} 57^{\prime} \mathrm{N}, 85^{\circ} 53^{\prime} \mathrm{W}\right)$. The field was bisected by a line of deciduous trees and was last cultivated in the early 1980 s. It was characterized by grasses with widely spaced shrubs and trees and contained a vernal pond of less than 0.25 ha. The field was bounded by an asphalt parking lot, a dirt road, a heavily used paved road and a golf course.

We used pipe-cleaner ligatures around the necks of nestlings to collect the boluses of insects delivered to them by adults because this technique provides an accurate representation of nestling diet (Johnson et al., 1980; Poulson and Aebischer, 1995; McCarty and Winkler, 1999). Even the smallest prey items were not likely to slip past ligatures because all items in a bolus of food were encased in a capsule of adult saliva. After ligatures were applied we observed adults delivering food to nest boxes and immediately collected boluses after adults exited nests and removed boluses from nestling throats with forceps and placed them in $70 \%$ ethanol. Parents delivered complete boluses to individual nestlings. Under a dissecting microscope we identified prey items in boluses using dichotomous keys (Borror $e t$ $a l ., 1989)$. Prey were identified to Order except Diptera which were identified to subordinal level as was done by Quinney and Ankney (1985). There were no demonstrable negative effects of ligatures on nestlings. Boluses were collected from 8- to $14 \mathrm{~d}$-old nestlings on 9 different days from 9-27 June. Most boluses were obtained during midday and, thus, provided an accurate indication of daily diet (McCarty, 1995). We did not measure insect availability or insect size.

We determined the dry weight of each bolus to $0.0001 \mathrm{~g}$ after drying in an oven for $48 \mathrm{~h}$ at $45 \mathrm{C}$. 
TABLE 1.-Tree swallow nestling diet items found in boluses $(n=89)$

\begin{tabular}{lcccc}
\hline \hline \multicolumn{1}{c}{ Prey item } & $\begin{array}{c}\text { Number in } \\
\text { boluses }\end{array}$ & $\begin{array}{c}\text { Percent of total } \\
\text { prey items }\end{array}$ & $\begin{array}{c}\text { Items per bolus } \\
\text { (mean } \pm \text { sD) }\end{array}$ & $\begin{array}{c}\text { Percent of } \\
\text { boluses }\end{array}$ \\
\hline Total Diptera & 1051 & 56.8 & $11.8 \pm 12.6$ & 96.6 \\
Brachycerous Diptera & 820 & 44.3 & $9.2 \pm 11.0$ & 95.5 \\
Nematocerous Diptera & 231 & 12.5 & $2.6 \pm 6.7$ & 56.2 \\
Hymenoptera & 269 & 14.5 & $3.0 \pm 6.8$ & 47.2 \\
Homoptera & 223 & 12.0 & $2.5 \pm 3.3$ & 69.7 \\
Coleoptera & 140 & 7.6 & $1.6 \pm 2.0$ & 58.4 \\
Ascaris & 57 & 3.1 & $0.6 \pm 3.0$ & 15.7 \\
Araneae & 32 & 1.7 & $0.4 \pm 0.8$ & 21.0 \\
Hemiptera & 30 & 1.6 & $0.3 \pm 0.6$ & 2.9 \\
Clam Shells & 17 & 0.9 & $0.2 \pm 1.2$ & 3.4 \\
Snail Shells & 15 & 0.8 & $0.2 \pm 0.9$ & 5.6 \\
Odonata & 8 & 0.4 & $0.1 \pm 0.3$ & 6.7 \\
Ephemerorata & 6 & 0.3 & $0.1 \pm 0.6$ & 1.1 \\
Lepidoptera & 3 & 0.2 & $0.0 \pm 0.2$ & 1.1 \\
Stones & 1 & 0.1 & $0.0 \pm 0.1$ & 1.1 \\
$\quad$ Totals & 1852 & & $21.8 \pm 16.3$ & \\
\hline
\end{tabular}

Dried boluses were heated in covered crucibles at $520 \mathrm{C}$ for $1 \mathrm{~h}$ to burn off organic material. After cooling for $1 \mathrm{~h}$ at ambient room temperature we weighed each bolus to $0.0001 \mathrm{~g}$. We calculated total organic weight as the difference between dry weight and postburn weight.

Air temperature, solar radiation and precipitation data were collected at an automated weather station located in a similar old-field habitat $<1 \mathrm{~km}$ from the study site. All data were analyzed using SPSS for Windows (SPSS 1995). All data were not normally distributed. Therefore, we used nonparametric Kruskal-Wallis analysis of variance $\left(\chi^{2}, \alpha=0.05\right)$ to compare the mean number of prey items/ bolus and mean dry and organic weight of boluses delivered to nestlings in broods of different sizes. We used Spearman's rank correlation test $\left(r_{s}, \alpha=0.05\right)$ to compare bolus composition with weather and date.

\section{RESULTS}

We collected 89 boluses containing 1852 items from 62 nestlings at 14 nests. Boluses contained 21.8 $\pm 16.3(\overline{\mathrm{x}} \pm \mathrm{SD})$ items (range $=1-88$ items/bolus). Mean bolus dry weight was $0.03 \pm 0.02 \mathrm{~g}(\mathrm{n}=89)$ and mean organic weight was $0.004 \pm 0.011 \mathrm{~g}(\mathrm{n}=64)$. There were fewer organic weight samples because 25 samples were accidentally destroyed after drying.

Boluses contained mostly intact arthropod prey. Nestling diets were composed of $44.28 \%$ Brachycerous Diptera, $12.5 \%$ Nematocerous Diptera, $12.0 \%$ Homoptera, $14.5 \%$ Hymenoptera and $7.6 \%$ Coleoptera. The remainder of diets included Ascaris, Araneae, Hemiptera, Odonata, Ephemeroptera, Lepidoptera, Mollusca (clam and snail shells) and stones (Table 1).

The mean number of prey items/bolus decreased significantly with increased brood size (Table 2). The mean number of prey items/bolus delivered to brood sizes of 4, 5 or 6 nestlings differed significantly $\left(\chi^{2}=20.05\right.$, $\mathrm{df}=2, \mathrm{P}<0.01$; Table 2$)$. However, neither mean bolus dry weight $\left(\chi^{2}=3.43\right.$, $\mathrm{df}=2, \mathrm{P}=0.18)$ nor mean bolus organic weight $\left(\chi^{2}=1.14, \mathrm{df}=2, \mathrm{P}=0.49\right)$ differed over the same brood sizes (Table 2).

The number of items/bolus was not significantly correlated with date of bolus collection $\left(r_{s}=0.05\right)$ or time $\left(r_{s}=-0.12\right)$, air temperature $\left(r_{s}=0.02\right)$, wind speed $\left(r_{s}=0.19\right)$ or solar radiation $\left(r_{s}=\right.$ $-0.11)$ at time of bolus collection. Mean temperature $\left(r_{s}=0.31\right)$ and solar radiation $\left(r_{s}=-0.03\right)$ during bolus collection were not significantly correlated with date. There were no significant correlations between weather conditions during bolus collection and the number of any of the different items/ 
TABLE 2.-Brood size and bolus size. Diet items per bolus and mean bolus dry and organic weight are indicated as mean $\pm \mathrm{SD}$

\begin{tabular}{cccccc}
\hline \hline $\begin{array}{c}\text { Brood } \\
\text { size }\end{array}$ & Nests & $\begin{array}{c}\text { Boluses } \\
\text { collected }\end{array}$ & $\begin{array}{c}\text { Diet items } \\
\text { per bolus }\end{array}$ & $\begin{array}{c}\text { Bolus dry weight } \\
(\mathrm{g})\end{array}$ & $\begin{array}{c}\text { Bolus organic weight } \\
(\mathrm{g})\end{array}$ \\
\hline 1 & 1 & 2 & $60.0 \pm 39.6$ & $0.017 \pm 0.005$ & $0.0024 \pm 0.0033$ \\
3 & 1 & 5 & $22.4 \pm 25.2$ & $0.028 \pm 0.013$ & $0.0073 \pm 0.0140$ \\
4 & 5 & 35 & $27.1 \pm 15.6$ & $0.027 \pm 0.014$ & $0.0013 \pm 0.0015(\mathrm{n}=21)$ \\
5 & 4 & 23 & $18.7 \pm 10.4$ & $0.030 \pm 0.019$ & $0.0075 \pm 0.0190(\mathrm{n}=15)$ \\
6 & 3 & 24 & $10.6 \pm 8.9$ & $0.039 \pm 0.038$ & $0.0030 \pm 0.0072(\mathrm{n}=21)$ \\
\hline
\end{tabular}

bolus. However, the mean number of Coleoptera/bolus $\left(r_{s}=0.93, P<0.001\right)$ and Hymenoptera/ bolus $\left(r_{s}=0.73, P<0.05\right)$ significantly increased with date, whereas the mean number of Nematocerous Diptera/bolus $\left(r_{s}=-0.75, P<0.05\right)$ significantly decreased with date.

\section{Discussion}

Diptera were the most common food items in the diets of nestling tree swallows in an upland old field in lower west Michigan. Homoptera, Hymenoptera and Coleoptera were also important food items. Bolus composition was not influenced by weather conditions.

Our study was consistent with other observations of empty mollusk shells in tree swallow diets (Mayoh and Zach, 1986; Blancher et al., 1987; Blancher and McNicol, 1988; St. Louis and Breebaart, 1991). Snail and clam shells may provide nestlings with supplemental dietary calcium (St. Louis and Breebaart, 1991) because their main diet items, insects, are low in calcium (Studier and Sevick, 1992). Dietary calcium is important to nestling birds because of the physiological demand for calcium for bone growth (Fisher, 1972; St. Louis and Breebaart, 1991; Barclay, 1994). Alternatively, these items may be used as grit (Mayoh and Zach, 1986), which may account for the stone found in one bolus.

The number of items/bolus delivered to a nestling was related to brood size (Table 2). Parents provisioning larger broods make more feeding visits per hour to broods than do parents of smaller broods (Lombardo, 1991). Parents could compensate for delivering fewer items/bolus to nestlings in larger broods by delivering heavier boluses (Walsh, 1978). However, we found no difference in the amount of food (dry weight and organic matter) delivered to nestlings over brood sizes 4-6 nestlings. Similarly, purple martin (Progne subis) parents increased the frequency of feeding visits to larger broods but did not deliver heavier boluses (Walsh, 1978). In contrast, great tit (Parus major) nestlings in smaller broods were fed heavier prey items than were nestlings in larger broods (Royama, 1966). The difference between tits and swallows may be that tits typically deliver single prey items (e.g., caterpillars) to nestlings whereas swallows deliver boluses that contain many prey items (Walsh, 1978).

Like other studies on tree swallow nestling diets in different habitats (Quinney and Ankney, 1985; Blancher et al., 1987; Blancher and McNicol, 1991), Diptera were the most common nestling diet item. Homoptera were an important food source at all locations but Odonata and Ephemeroptera were more common in wetlands than in drier regions. Thus, the types of insects selected by parents to feed nestlings may depend upon availability.

Acknowledgments.-We thank E. H. Burtt, Jr. for comments on a previous version of the manuscript, J. P. McCarty for advice and providing unpublished data, J. Cooper for advice on weighing insects and M. Northup for providing weather data. This study was supported by the Department of Biology at Grand Valley State University.

\section{LITERATURE CiTED}

BARCLAY, R. M. R. 1994. Constraints on reproduction by flying vertebrates: energy and calcium. Am. Nat., 144:1021-1031.

BEAL, F. E. L. 1918. Food habits of the swallows, a family of valuable native birds. U.S. Dept. Agric. Bull., 619. 
Blancher, P. J., C. L. Furlonger AND D. K. MCNicol. 1987. Diet of nestling tree swallows (Tachycineta bicolor) near Sudbury, Ontario, summer 1986. Tech. Rep. Ser. No. 31. Can. Wildl. Serv., Ont. Reg.

- AND D. K. MCNiCOL. Tree swallow diet in relation to wetland acidity. Can. J. Zool., 69:26292637.

BOAG, P. T. 1987. Effects of nestling diet on growth and adult size of zebra finches (Poephila guttata). $A u k$, 104:155-166.

Borror, D. J., C. A. Triplehorn and N. F. Johnson. 1989. An introduction to the study of insects, 6th ed. Saunders College Publishing, New York. 800 p.

Fisher, H. 1972. The nutrition of birds. Avian biology, Vol. 2., pp. 431-469. Academic Press, New York.

Johnson, E. J., L. B. BEST AND P. A. HEAGy. 1980. Food sampling biases associated with the "ligature method". Condor, 82:186-192.

KREBS, J. R. AND M. I. AVERY. 1984. Diet and nestling growth in the European bee-eater. Oecologia, 64: 363-368.

LACK, D. 1968. Ecological adaptations for breeding in birds. Methuen, London. 409 p.

LOMBARDO, M. P. 1991. Sexual differences in parental effort during the nestling period in tree swallows (Tachycineta bicolor). Auk, 108:393-404.

MCCARTY, J. P. 1995. Effects of short-term changes in environmental conditions on the foraging ecology and reproductive success of tree swallows, Tachycineta bicolor. Ph.D. Dissertation, Cornell University, Ithaca, New York. 305 p.

- AND D. W. WINKLER. 1999. Foraging ecology and diet selectivity of tree swallows feeding nestlings. Condor, 101:246-254.

MAYOH, K. R. AND R. ZACH. 1986. Grit ingestion by nestling tree swallows and house wrens. Can. J. Zool., 64:2090-2093.

O'Connor, R. J. 1984. The growth and development of birds. John Wiley \& Sons, New York. 315 p.

PERrINS, C. M. 1980. Survival of young great tits, Parus major. Acta XVII Congr. Int. Orn. Berlin, 17: $159-174$.

Poulson, J. G. AND N. J. Aebischer. 1995. Quantitative comparison of two methods of assessing diet of nestling skylarks (Alauda arvensis). Auk, 112:1070-1073.

Quinney, T. E. AND C. D. ANKNEY. 1985. Prey size selection by tree swallows. Auk, 102:245-250.

, D. J. T. Hussell AND C. D. ANKNEY. 1986. Sources of variation in growth of tree swallows. Auk, 103:389-400.

RoYAMA, T. 1966. Factors governing feeding rate, food requirement and brood size of nestling great tits Parus major. Ibis, 108:313-347.

ST. Louis, V. L. AND L. BREEBAART. 1991. Calcium supplements in the diet of nestling tree swallows near acid sensitive lakes. Condor, 93:286-294.

SPSS. 1995. SPSS for Windows Version 6.1.3. SPSS, Inc., Chicago.

SMITH, H. K. 1988. Reproductive costs and offspring quality: the evolution of clutch size in tits (Parus). Ph.D. Dissertation, Lund Univ., Lund, Sweden. 113 p.

Street, M. AND T. MacDonald. 1977. Amey Roadside wildfowl project: 1976. Annu. Rev. Game Conservancy, 1976:35-43.

STUdiER, E. H. AND S. H. SEVICK. 1992. Live mass, water content, nitrogen and mineral levels in some insects from south-central lower Michigan. Comp. Biochem. and Physiol. A, Comp. Physiol., 103: 579-595.

WALSH, H. 1978. Food of nestling purple martins. Wilson Bull., 90:248-260.

MATTHEW E. JOHNSON AND MICHAEL P. LOMBARDO' ${ }^{1}$, Department of Biology, Grand Valley State University, Allendale, Michigan 49401.

Submitted August 1999; accepted 31 January 2000.

\footnotetext{
${ }^{1}$ Corresponding author: Telephone (616)895-2501; FAX (616)895-3446; e-mail lombardm@gvsu.edu
} 